\title{
Distribution of urban green spaces: Comparative analysis between cities in different countries
}

\author{
Cecília Souza Gontijo Garcia ${ }^{1}$, Patrícia Duarte de Oliveira Paiva $2^{2 *}$, \\ Jules Bruck ${ }^{3}$ [D, Rafael de Brito Sousa ${ }^{2}$ (D) \\ ${ }^{1}$ Centro Universitário de Lavras (UNILAVRAS), Lavras-MG, Brazil. \\ ${ }^{2}$ Universidade Federal de Lavras (UFLA). Departamento de Agricultura, Lavras-MG, Brazil. \\ ${ }^{3}$ University of Delaware, Department of Plant and Soil Sciences, Newark-DE, USA.
}

\begin{abstract}
The presence of urban green spaces (UGS) increases the human's contact with nature and provides numerous benefits to the society and the local environment. In this way, analyzing, planning and stimulating the implementation of UGS in cities is a fundamental action to improve the life quality of urban society. In this context, the aim was to analyze the situation and distribution of the green spaces of the universities cities of Lavras, Minas Gerais State (Brazil) and Newark, Delaware (USA). For data collection, researches performed field visits and used aerial photography to survey and analysis before calculating indicators including green area index (GAI) and green space ratio (GSR). The city of Lavras has a GAI of $0.54 \mathrm{~m}^{2} \mathrm{inh}^{-1}$. The GSR value was $0.29 \%$, not meeting the minimum of $5 \%$ required by local municipal law. Furthermore, there is a bad distribution of UGSs in the urban framework. However, in Newark, the distribution of UGSs is homogeneous and covers all regions of the city. The calculated GAI was $50.2 \mathrm{~m}^{2} \mathrm{inh}^{-1}$ and the GSR has met the 7\% minimum required by its Newark Municipal Law. When comparing the two cities, in different countries and conditions it is concluded that Newark (DE) presents UGS indicators, GAI $\left(\mathrm{m}^{2}\right.$ inh $\left.^{-1}\right)$ and GSR (\%), higher than the values obtained in Lavras (MG), indicating the need for Government actions to increase these values.
\end{abstract}

Keywords: green area index, landscape architecture, life quality, parks, squares.

\section{Resumo}

Distribuição das áreas verdes públicas: análise comparativa entre cidades em diferentes países

As áreas verdes públicas urbanas (AVPs) concebem um importante tema, pois sua presença nas cidades, ampliando o contato do homem com a natureza, além dos efeitos ambientais geram inúmeros benefícios. Dessa maneira, analisar, planejar e estimular a implantação das AVPs nas cidades é ação fundamental para a melhoria da qualidade de vida da sociedade urbana. Nesse contexto objetivou-se analisar a situação e distribuição das áreas verdes das cidades universitárias de Lavras, estado de Minas Gerais, Brasil e Newark, estado de Delaware, EUA. Para a coleta de dados foram realizadas visitas a campo e o levantamento de áreas das AVPs por meio da análise de imagens de satélite utilizando o software ArcGIS e calculados os indicadores, índice de áreas verdes (IAV) e percentual de áreas verdes (PAV). A cidade de Lavras possui um IAV de $0,54 \mathrm{~m}^{2}$ hab ${ }^{-1}$. O valor de PAV foi de $0,29 \%$, não cumprindo o mínimo de 5\% exigido pela lei municipal local. Além disto, existe uma má distribuição das AVPs na malha urbana. Já em Newark,

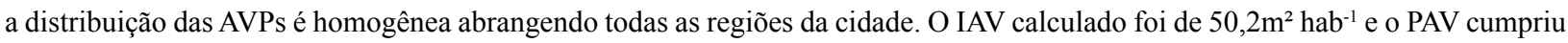
o mínimo de 7\% exigido pela sua Lei municipal de Newark. Ao comparar as duas cidades, conclui-se que Newark (DE) apresenta indicadores sobre as áreas verdes públicas, IAV $\left(\mathrm{m}^{2} \mathrm{hab}^{-1}\right)$ e PAV (\%) superiores em comparação aos valores obtidos em Lavras (MG), indicando a necessidade de ações governamentais para ampliar esses valores.

Palavras-chave: índice de áreas verdes, paisagismo, qualidade de vida, parques, praças.

*Corresponding author: patriciapaiva@ufla.br 


\section{Introduction}

In recent decades, urban growth without adequate planning resulted in the consequent absence of urban green spaces (UGSs) in urban centers. Lack of green spaces in urban areas contributes to negative effects on the environment and public health. Factors such as high pollution and $\mathrm{CO}_{2}$ indices, ecological imbalances, and a high degree of physical and mental stress (Person et al., 2019; Comune and Suriani-Affonso, 2014) are contributed to urban environments lacking green spaces.

Located within the urban perimeter, an UGS is considered the vegetated public spaces of an urban location that serves the ecological, aesthetic and leisure functions of the population and includes $70 \%$ or more permeable area (Boldrin, 2016). Besides of this, in some situations, is also an important attractive area for tourism (Paiva et al., 2020).

Understanding of the importance and necessity of the presence of UGSs in urban environments and the benefits of man's contact with nature are well documented and include overall improvements in the quality of life within society (Lafortezza et al., 2009; Carrus et al., 2015). In this way, the planning and implementation of UGSs are fundamental for reaching healthy, safe and sustainable cities (Chiesura, 2004, Fernandes et al., 2018) in order to maximize the benefits propitiated by these areas as example, pollution control, areas for activities (Salgado et al., 2020), biodiversity (Schebella et al., 2019), tourism activities (Silva et al., 2019; Paiva et al., 2020) and others.

Although many cities include UGSs for the population to enjoy leisure moments and contact with nature, few have UGSs laid out in an organized or connected way contributing to fragmented green spaces within the urban framework. Besides this fragmentation, UGSs are often unevenly distributed in space - heterogeneous (Rigolon, 2016).

Different tools and methods are used to analyze UGSs within the urban framework. In Brazil, USA, and in some European countries, the methodology most used for this analysis is the green area index (GAI) per inhabitant and the green space ratio (GSR). The GAI and GSR have parameters of consideration for the evaluation and analysis of the quality of cities (Boone et al., 2009; Kabisch and Haase, 2014). GAI is expressed in $\mathrm{m}^{2}$ inh $^{-1}$, and the GSR is the percentage value that UGSs occupy in the extension of an urban area being considered. Using these indices, it is possible to optimize urban management and to obtain more sustainable and livable cities (Carrus et al., 2015).

In this context, the aim of this research was to perform a comparative analysis of the situation and distribution of green spaces by determining the GAI and the GSR of two cities: Lavras in the state of Minas Gerais (MG) and Newark, Delaware (DE), US. The cities were chosen as case studies because each has similar urban characteristics: both are suburban university cities with similarly sized seasonal populations. They are different situationally as they are located in countries with different human development index (HDI).

\section{Material and Methods}

\section{Study areas}

The study was conducted on two cities including Newark, Delaware, United States and Lavras, Minas Gerais State, Brazil. The US is considered as developed country with an HDI of 0.920 , occupying 10th place in the world ranking according to the Human Development Report of the United Nations. Lavras is located in Brazil which is a developing country with an HDI of 0.754 , occupying the 79th place in this same world ranking (UNDP, 2016).

These cities have different climatic, size, density, and territorial characteristics. However, they were selected because they present common features. Both cities include similarly sized universities in their respective countries, and therefore, have a representative floating population (members and students of the Universities) adding to the total residents for a large portion of the year. Both cities also have target goals in their comprehensive plans indicating the quantity of green spaces that must be made to the public.

The city of Lavras is located in the Campos das Vertentes region in Minas Gerais State, Brazil, at $21^{\circ} 14^{\prime} 30^{\prime \prime} \mathrm{S}, 44^{\circ} 00^{\prime} 10^{\prime} \mathrm{W}$, and $919 \mathrm{~m}$ altitude. The climate is Cwa according to Köppen classification, temperate rainy (mesothermic) with dry winters and wet summers, denominated subtropical (Dantas et al., 2007). It has an annual average temperature of $19.4{ }^{\circ} \mathrm{C}$, rainfall of 1530 $\mathrm{mm}$ and relative humidity of $76 \%$ per year (Sparovek et al., 2007).

Lavras has a total territorial extension of $564.7 \mathrm{~km}^{2}$, from which $54.6 \mathrm{~km}^{2}$ are considered urban territory. The population living in the urban area represents the approximate sum of undergraduate and graduate students attending the university in Lavras, approximately 14,378, which is referred to as the floating population (UFLA, 2016; UNILAVRAS, 2016) and permanent residents. The number of permanent residents in July 2016 was 96,209 (IBGE, 2016). The estimated current urban resident population in Lavras, inclusive of the floating population, is approximately 110,587 people. The resulting urban population density is 2,025 inhabitants per $\mathrm{km}^{2}$ (IBGE, 2016; UFLA, 2016; UNILAVRAS, 2016).

In 2012, Lavras had 35 squares, but only 24 included required characteristics to be considered an UGSs. These 24 squares had a total area of 40,732 $\mathrm{m}^{2}$. Lavras also has one park, the Ecological Park Quedas do Rio Bonito, located $9 \mathrm{~km}$ away from the city which is not included in the area description (Boldrin et al., 2016).

Newark is located in the state of Delaware, New Castle County, United States, at 39 66'94" N and 75'75'14" W, and $30 \mathrm{~m}$ altitude. The climate is Cfa according to Köppen classification, with significant annual rainfall of $1099 \mathrm{~mm}$ on average. The average yearly temperature is $13.0^{\circ} \mathrm{C}$ (U.S. Climate data, 2016). This city has a total urban area of only $41 \mathrm{~km}^{2}$. In the year 2015 , the population was estimated at 33,817 inhabitants with $100 \%$ considered as urban residents. The floating population is comprised of undergraduate and 
graduate students attending the University of Delaware. The total UD student population was 22,852 students (UD, 2015). The total number of people living in Newark was 56,669 . The density is equivalent to 1,382 inhabitants per $\mathrm{km}^{2}$ in 2015 (Table 1) (US Census Bureau, 2016).

\section{Quantitative and qualitative analyses of urban green spaces}

The UGSs were classified by their quantitative and qualitative characteristics, observed in visits performed to the areas. In Newark, field visits were conducted to identify, classify and recognize the UGSs of the city. Quantitative analyses were performed using the ArcGIS 10.3 software. An orthophoto registered in March 2012 with $30 \mathrm{~cm}$ (or $0.3 \mathrm{~m}$ ) spatial resolution was used to map the UGSs of and Delaware State Plane Coordinate System Meters was used for Newark. The green space maps were visually analyzed based on the orthophoto, and the data was further analyzed using Microsoft Excel 2016 software. All areas considered UGSs were traced and measured then edited to create illustrative maps representing the current status of green spaces including the distribution within the urban framework. In Lavras, since was not available orthophotos from the areas, a field visit and a visual characterization was essential to classify the areas. For this classification, the letters $\mathrm{A}, \mathrm{B}, \mathrm{C}, \mathrm{D}, \mathrm{F}$, and $\mathrm{G}$ were assigned for the following characteristics: A: no physical/plant structure; $\mathrm{B}$ : impermeabilized; C: no maintenance; D: no leisure; E: construction of houses, buildings or others; F: inexistent; G: meets all the UGS criteria (Boldrin et al., 2016). Areas classified as $\mathrm{E}$ or $\mathrm{F}$ were not considered for quantitative analysis (indices, percentages).

The procedures performed for the evaluation of the UGSs of the city of Lavras were performed using ArcGIS 10.3 software and data were analyzed in the Microsoft Excel 2016 software. For the city of Lavras, an orthorectified aerial photograph $(=$ orthophoto) registered in October 2014 was used with a spatial resolution of $7.0 \mathrm{~cm}$ (or 0.07 $\mathrm{m}$ ), and UTM - WGS 84 coordinate system provided by the city hall of Lavras.

The maps of green spaces were designed through visual analysis of the orthophoto and verified jointly to the database of the city hall and previous studies. Field visits were also made for a conference and qualitative evaluation of the current state of the study areas.

In order to evaluate and compare the area and quality of the UGSs in both cities, some characteristics were considered as the distribution, the Green area index (GAI), the green space ratio (GSR).

\section{Distribution of urban green spaces in the cities}

In the assessment of the UGS distribution in the urban framework, it was considered a radius of influence of $800 \mathrm{~m}$ for the Newark parks because the city has a flat relief with easy access for its users. In contrast, the city of Lavras has a rugged relief, which hinders access to the green spaces.
Due to that, it was considered a shorter radius of influence of $400 \mathrm{~m}$, in order to counterbalance the relief limitations. To delimit the area with influence of the parks and squares, the buffer tool of ArcGIS software (Araújo and Ferreira, 2014) was used.

\section{Calculation of green area index (GAI)}

The GAI is calculate by dividing the total area $\left(\mathrm{m}^{2}\right)$ of UGSs in a city per the number of inhabitants, resulting in $\mathrm{m}^{2}$ per inhabitant. Two GAIs were calculated for Newark: the first consisted of the sum of the total UGS area $\left(\mathrm{m}^{2}\right)$ divided by the estimated number of city's inhabitants in the year 2015; and the second considered the city's floating population (UD, 2015; US Census Bureau, 2016).

For Lavras, three different index situations were calculated: the first one consisted of the sum of the total square area $\left(\mathrm{m}^{2}\right)$ considered as suitable according to qualitative criteria (Boldrin, 2016) divided by the number of estimated city's urban residents in the year 2016 (IBGE, 2016). The second GAI accounted for the city's floating population (UFLA, 2016; UNILAVRAS, 2016). The third index considered the 131 urban sectors of the city (IBGE, 2016). As the division of neighborhoods and regions of cities is not defined precisely by the city hall, the division made by the Brazilian Institute of Geography and Statistics (IBGE) was adopted.

This third GAI was calculated for each census sector considered as urban (IBGE, 2016) in the city of Lavras. In this regard, it was observed which green spaces influence each sector, considering the radius of influence of $400 \mathrm{~m}$ (buffer) for the squares of Lavras. Since a sector can be affected by one or more green spaces, not have any UGS, or even not be influenced by them. Subsequently, the total area of UGSs for each census sector was divided by the estimated total of residents in the respective urban sectors in 2016. This information may have an idea of the GAI for each sector, basing on IBGE (2016) census, allowing the identification of regions deficient in green spaces.

\section{Calculation of green space ratio (GSR)}

To calculate the GSR of the cities, all UGSs $\left(\mathrm{m}^{2}\right)$ were summed, and it was calculated how much they represent in the percentage of the urban territorial extension of the respective cities. For the total area ofthe urban area of Newark, map files provided by the Department of Geography of the University of Delaware were used. This file corresponds to an online database provided by the Government of the United States.

Two urban perimeters were delimited for the city of Lavras and, therefore, two GSRs. For this, a total GSR was calculated through the generated map using the area extension data of the sectors considered as urban provided by the IBGE, and the other GSR was calculated according to the perimeter traced through the orthophoto in the ArcGIS 10.3 software, finding the indications of Complementary Law no. 156, from September 22, 2008 (Law on the use 
and occupation of urban land in the city of Lavras) and the city's master plan (Complementary Law No. 097, from April 17, 2007).

With the urban perimeters, it was possible to define the total urban areas of Lavras and Newark, besides calculating the total GSR of each city. Besides the different GSRs determined for Lavras, a GSR was also calculated for each urban census sector, thus allowing the identification of regions deficient in green spaces.

\section{Results and Discussion}

\section{Quantitative and qualitative analyses of urban} green spaces

\section{Urban green spaces of the city of Lavras}

After visiting all the areas in city of Lavras, a classification was performed, considering the quantitative area and conditions (quality) of the space. The results are shown on Table 1.

Table 1. Quantitative and qualitative analysis of the squares of Lavras-MG and their respective areas $\left(\mathrm{m}^{2}\right)$

\begin{tabular}{|c|c|c|c|c|c|c|c|}
\hline $\mathbf{N}$ & Name & $\begin{array}{c}\text { Area } \\
\left(\mathbf{m}^{2}\right)\end{array}$ & Analysis* & $\mathbf{N}$ & Name & $\begin{array}{c}\text { Area } \\
\left(\mathbf{m}^{2}\right)\end{array}$ & Analysis* \\
\hline 1 & Praça Dr. Leonardo Venerando & 2,594 & G & 24 & Praça s/n & 1,442 & G \\
\hline 2 & Praça Dr. Augusto Silva & 8,299 & G & 25 & Praça $s / n$ & 2,321 & G \\
\hline 3 & Praça Mariana Rosa de Souza & 4,450 & $\mathrm{~A} ; \mathrm{C} ; \mathrm{D}$ & 26 & Praça Juca da Serra & 1,080 & A; D \\
\hline 4 & Praça das Rosas & 1,499 & G & 27 & Praça Elba Terra & 208 & $\mathrm{D}$ \\
\hline 5 & Praça Maria Pádua Menicucci & 2,999 & $\mathrm{~A} ; \mathrm{C} ; \mathrm{D}$ & 28 & $\begin{array}{c}\text { Praça Floriano Ignácio de } \\
\text { Jesus }\end{array}$ & 1,336 & G \\
\hline 6 & Praça dos Crisântemos & 1,513 & G & 29 & Praça John Wheelook & 2,472 & G \\
\hline 7 & Praça Sebastião Alcântra & 4,890 & G & 30 & Praça $s / n$ & 812 & G \\
\hline 8 & Praça São Pedro & 480 & G & 31 & Praça s/n & 2,977 & G \\
\hline 9 & Praça José Esteves & 3,425 & G & 32 & Praça Artur Santos Penoni & 306 & G \\
\hline 10 & Praça Dr. Jorge & 2,265 & G & 33 & Praça $s / n$ & 1,598 & G \\
\hline 11 & $\begin{array}{c}\text { Praça Monsenhor Domingos } \\
\text { Pinheiro }\end{array}$ & 1,315 & G & 34 & Praça s/n & 2,920 & $\mathrm{~F}$ \\
\hline 12 & Praça Dona Josefina & 675 & G & 35 & Praça s/n & 6,050 & G \\
\hline 13 & $\begin{array}{c}\text { Praça Tenente Francisco Souza } \\
\text { Lima }\end{array}$ & 795 & G & 36 & Praça das Margaridas & 1,835 & $\mathrm{~F}$ \\
\hline 14 & Praça Bocaina & 1,499 & G & 37 & Praça s/n & 621 & G \\
\hline 15 & Praça s/n & 2,005 & G & 38 & Praça João Albex & 106 & $\mathrm{D}$ \\
\hline 16 & Praça Dr. Rafael Menicucci & 2,209 & G & 39 & Praça s/n & 673 & G \\
\hline 17 & Praça Joaquim Vitor & 558 & G & 40 & Praça do Cruzeiro & 161 & B; D \\
\hline 18 & Praça dos Governadores & 375 & $\mathrm{C} ; \mathrm{D}$ & 41 & Praça Duque da Rocha & 597 & $\mathrm{E}$ \\
\hline 19 & Praça Gilbram Simão & 961 & $\mathrm{~A} ; \mathrm{C} ; \mathrm{D}$ & 42 & Praça s/n & 0 & $\mathrm{~F}$ \\
\hline 20 & Praça da Igreja São Sebastião & 2,025 & G & 43 & Praça $s / n$ & 0 & $\mathrm{~F}$ \\
\hline 21 & Praça s/n & 494 & G & 44 & Praça $s / n$ & 479 & $\mathrm{D}$ \\
\hline 22 & Praça s/n & 981 & G & 45 & Praça $\mathrm{s} / \mathrm{n}$ & 0 & $\mathrm{~F}$ \\
\hline 23 & Praça Antônio Vilela de Andrade & 1,234 & G & & & & \\
\hline \multicolumn{4}{|c|}{ Total urban green space $\left(\mathbf{m}^{2}\right)$} & \multicolumn{4}{|c|}{75,534} \\
\hline \multicolumn{4}{|c|}{ Total area used for calculation of GAI $\left(\mathrm{m}^{2}\right)$} & \multicolumn{4}{|c|}{59,363} \\
\hline
\end{tabular}

\footnotetext{
* A: no physical/plant structure; B: impermeabilized; C: no maintenance; D: no leisure; E: construction of houses, buildings or others; F: inexistent; G: meets all the UGS criteria.

Obs.: Praça means Square; $\mathrm{s} / \mathrm{n}=$ no denomination
} 
In both cities, many permeable areas such as private gardens (including university areas), clubs, median strips, and roundabouts were not considered for evaluation. In Lavras, the nearby park, Ecological Park Quedas does Rio Bonito (Carvalho et al., 2003) was not considered in calculations because of its location in a rural area outside the urban perimeter.
After mapping the Lavras squares, it was possible to perform a general analysis of the regions of the city influenced or not by the UGSs. Using the buffer tool in the ArcGIS software, it was observed the absence of UGSs in many regions of the city. Except central areas, most Lavras neighborhoods do not have or are not under the influence of any UGS (Figure 1).

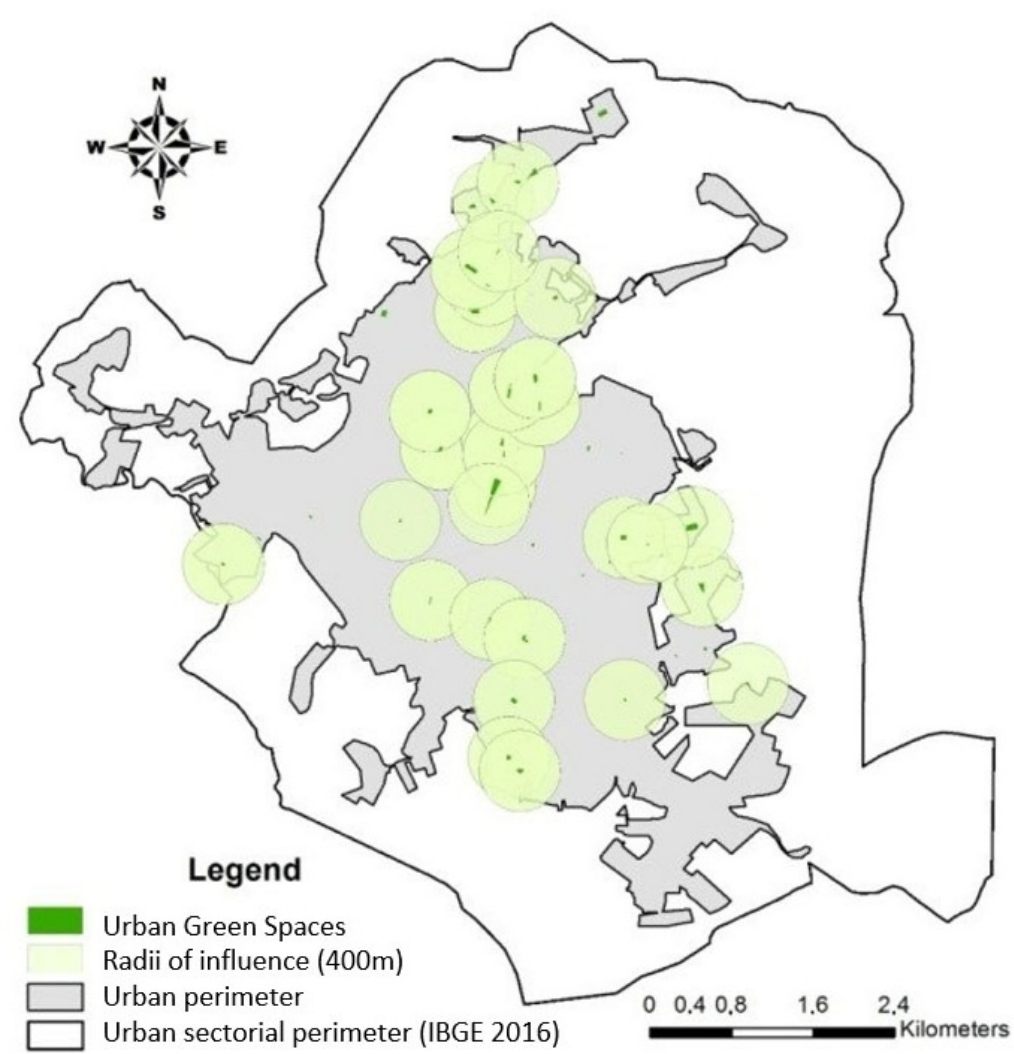

Figure 1. Urban boundaries of Lavras (Brazil) and its urban green spaces with their respective radii of influence.

Considering all the UGSs of the city, i.e., 45 squares, there is $75,534 \mathrm{~m}^{2}$. However, only 30 squares had characteristics that allow them to be considered as UGSs, totaling 59,363 $\mathrm{m}^{2}$ (Table 1 ).

Considering the map of Lavras generated by IBGE with urban territory equal to $54.6 \mathrm{~km}^{2}$, the UGSs occupy approximately $0.11 \%$ (GSR). When considering the traced urban boundaries, the GSR increases to $0.29 \%$, since the area considered as urban is $20.3 \mathrm{~km}^{2}$ (Figure 1). The ideal reference value of GSR based on the municipal legislation of Lavras is $5 \%$. Therefore, according to the own legislation, it is evidenced that the city has a deficiency in green spaces in its urban framework. As a comparison, the GSR of some Brazilian cities corresponds to: Londrina-PR, 16,25\% (Barros and Virgilio, 2003), Paulínia-SP, 6.3\% (Bargos and Matias, 2012), and Sorocaba-SP, 20\% (Bressane et al., 2015). In Lavras, besides not reaching the minimum 5\% required by municipal legislation, it still has lower GSR than other Brazilian cities that have a similar size.

With the mapping (Figure 1), different indices of GAIs per inhabitant were also calculated. For the first index, only the estimated number of urban residents for the year 2016 (IBGE, 2016) was used in the calculation. This resulted in a GAI for the city of Lavras of $0.62 \mathrm{~m}^{2} \mathrm{inh}^{-1}$. When considering the floating population, this index is reduced to $0.54 \mathrm{~m}^{2} \mathrm{inh}^{-1}$. Nevertheless, both indices are still below $15 \mathrm{~m}^{2} \mathrm{inh}^{-1}$, which is the recommended by the Brazilian society of urban afforestation (SBAU, 1996), the standard index in the UGS analysis of Brazilian cities.

Comparing the data generated on Lavras with other indexes already studied in cities of Brazil, it has the following GAIs: São Paulo-SP, $2.9 \mathrm{~m}^{2} \mathrm{inh}^{-1}$ (Nucci, 2001); Uberlândia-MG, $6.6 \mathrm{~m}^{2}$ inh$^{-1}$ (Toledo et al., 2009); JataíGO, $5.31 \mathrm{~m}^{2}$ inh $^{-1}$ (Souza et al., 2014). All these indices, although they are below the recommended of $15 \mathrm{~m}^{2} \mathrm{inh}^{-}$ ${ }^{1}$ (SBAU, 1996), are still superior to those obtained for Lavras-MG.

Considering the possibility of performing actions for the recovery of the UGSs of Lavras and if all existing squares offered acceptable characteristics to be included in this index, the value would be $0.79 \mathrm{~m}^{2} \mathrm{inh}^{-1}$, without considering the floating population of $0.68 \mathrm{~m}^{2} \mathrm{inh}^{-1}$. Even 
so, the index would be much lower than the $15 \mathrm{~m}^{2} \mathrm{inh}^{-1}$ (SBAU, 1996).

In a survey conducted in 2002, a GAI of 0.33 was found for Lavras, and ten years later, in 2012, this index was 0.42 (Boldrin et al., 2016). Thus, it is possible to realize that, until 2016, there was a small increase in the GAI of Lavras, reaching $0.62 \mathrm{~m}^{2} \mathrm{inh}^{-1}$, which is due to the squares built in new allotments of the city. Under the supplementary municipal law $n^{\circ} 155$, from August 28, 2008, all allotment must contain area(s) intended for a public square, in the proportion of 5\% (five percent) of the total plot area and $20 \%$ of these should have natural declivity lower than $15 \%$. It is possible to infer that, in recent years, greater compliance with the law associated with the construction companies' concern to better plan the UGSs of the new allotments is a consequence of the higher demand and requirement of the society, associated to the real estate valuation that the presence of these UGSs can add to the enterprise (Escobedo et al., 2015).

The joint analysis of the distribution map of the UGSs and the valuesobtained from the indices revealed that the simplified calculation of GAI and GSR could lead to the incorrect homogenization of spatial information. Therefore, the most representative would be the evaluation of the distribution of green spaces by the census sector in the urban area of Lavras by calculating GAI and its GSR in each urban census sector.

From the 131 urban census sectors in the city of Lavras, $25(19 \%)$ of them have GAI equal to zero. The sum of inhabitants of these sectors corresponds to 15,546 residents, in other words, inhabitants do not own and are not influenced by any UGS. In the same way, another 73 sectors showed GAI between 0.1 and 7.5, and another 11 sectors had GAI between 7.6 and 15.0 (Figure 2).

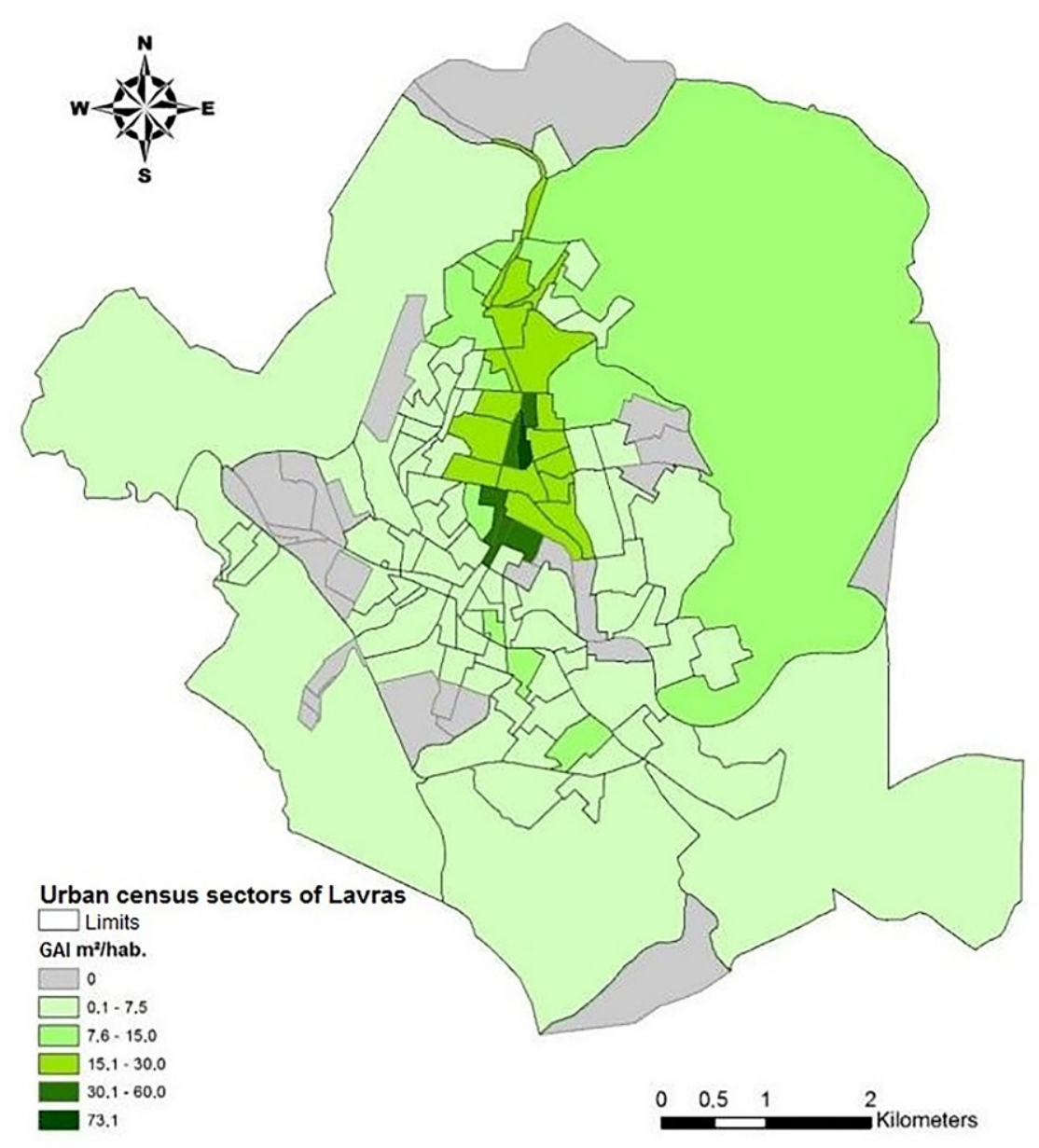

Figure 2. Urban sectors of Lavras (MG) and their green area indexes (GAI) 
According to the analysis, 110 of the total 131 urban sectors in the city of Lavras have GAI below the recommended level of $15 \mathrm{~m}^{2} \mathrm{inh}^{-1}$, i.e., 86,032 residents in the urban framework of the city of Lavras (89.4\%) do not have access to the minimum UGSs recommended by the Brazilian Society of Urban Afforestation (SBAU, 1996). Only 22 sectors showed higher than the recommended GAI of $15 \mathrm{~m}^{2}$ inh $^{-1}$, highlighting sectors 5 and 132 with the highest indexes, 73.1 and
55.5, respectively. These sectors are neighbors and are located in the central area of the city (Table 2), influenced by six squares, totaling an area of $16,624.00$ $\mathrm{m}^{2}$, from which four are the main squares of the city (Praça Dr. Augusto Silva, Praça Monsenhor Domingos Pinheiro, Praça D. Josefina, Praça Dr. Jorge) (Figure 2 ). This shows that the central region is prioritized about the peripheral regions about the installation of this type of urban structure.

Table 2. Number of urban sectors with results of green area indexes $\left(\mathrm{m}^{2} \mathrm{inh}^{-1}\right)$ and green space ratios $(\mathrm{GSR} \%)$ of the city of Lavras-MG, Brazil.

\begin{tabular}{|c|c|c|c|}
\hline GAI $\left(\mathbf{m}^{\mathbf{2}} \mathbf{~ i n h}^{-\mathbf{1}}\right)$ & $\mathbf{N}^{\mathbf{0}}$ urban sectors & GSR (\%) & $\mathbf{N}^{\mathbf{0}}$ urban sectors \\
\hline 0 & 25 & $0 \%$ & 105 \\
\hline 0.1 to 7.5 & 73 & 0.1 to $1.0 \%$ & 11 \\
\hline 7.6 to 15 & 11 & 1.1 to $2.0 \%$ & 8 \\
\hline 15.1 to 30 & 16 & 2.1 to $3.0 \%$ & 2 \\
\hline 30.1 to 60 & 5 & 4.1 to $5.0 \%$ & 2 \\
\hline 73.1 & 1 & 5.1 to $6.0 \%$ & 3 \\
\hline
\end{tabular}

For the GAI calculation of each sector, the radius of influence of $400 \mathrm{~m}$ for each green area was considered. Thus, a square could influence one or more sectors. If this GAI calculation of each sector was measured considering only the squares inserted in the sectors and did not take into account their radius of influence, several of these sectors would have GAI much below that demonstrated. This was observed in the city of Juiz de Fora-MG, when 48 of the 81 urban regions of the city showed GAI equal to zero and in only two regions of the city, this index was higher than 15 $\mathrm{m}^{2}$ inh $^{-1}$ (Araújo and Ferreira, 2014)

To complement these results and to understand the situation and distribution of the UGSs in the city of Lavras, the GSR was calculated for each urban sector (Figure 3).

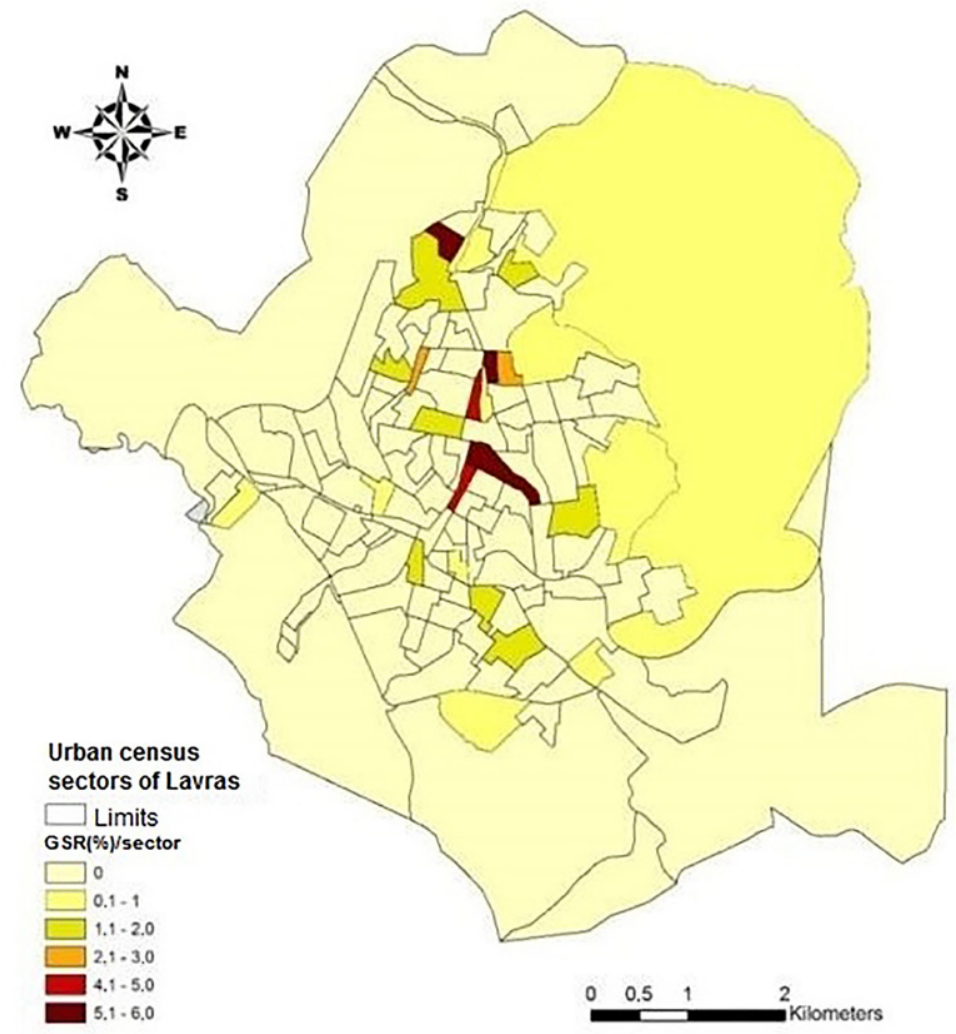

Figure 3. Urban sectors of Lavras (MG) and its green space ratios (GSR). 
The data show that 105 of the 131 urban sectors have GSR equal to $0 \%$, i.e., they do not have any UGS (Figure 3 ). Considering the sum of the areas of these sectors, we have that $49.6 \mathrm{~km}^{2}$, i.e., $90.8 \%$ of the city's urban framework does not have any GSR in its extension. This means that only 27 urban sectors of Lavras have some UGS, from which 11 sectors have GSR from $0.1 \%$ to $1.0 \%$, another eight sectors have GSR between 1.1 and $2.0 \%$, and two sectors have GSR of $2.3 \%$ and $2.9 \%$ respectively, and another two with GSR of 4.1 and 5.0\%. Only three sectors had GSR greater than $5 \%$, as required by the municipal law of the city of Lavras, being: $5.9 \%$ - sector $73 \%$ and 5.3\% - sectors 8 and 29 (Table 2). Coincidentally, the division made by the IBGE, are inserted in these sectors large squares, which caused that these GSRs resulted in considerable values.

The same can be observed in the city of Juiz de Fora, where it was verified that $2 / 3$ of the urban regions of the city presented GSR between 0 and $0.1 \%$, however, the average value also does not reach 5\% (Araújo and Ferreira,
2014). In contrast to Sorocaba-SP, where GSR is different in the city regions, but in a well-distributed way, with an average value of $20 \%$ (Bressane et al., 2015).

\section{Urban green spaces of the city of Newark-DE}

After analyzing the UGS mapping and their radii of influence, it was possible to observe that the city of Newark has several UGSs and a proper distribution in its territory. The city does not have any place characterized as a square, were all considered as parks. In the city, there are 28 urban public parks, with a total extension of $2.8 \mathrm{~km}^{2}$, thus representing $7 \%$ (GSR) from the total area $\left(41 \mathrm{~km}^{2}\right)$ of its territory (Table 3 ). The total GAI obtained was $84.3 \mathrm{~m}^{2}$ inh $^{-1}$ without counting the floating population. By including the floating population in the GAI calculation, this index is reduced to $50.2 \mathrm{~m}^{2} \mathrm{inh}^{-1}$. Thereby, the GSR of the city reached the minimum recommended by municipal law, which is 7\% (Municipal code, 2016), being considered as appropriate.

Table 3. Public parks and their respective areas $\left(\mathrm{m}^{2}\right)$ of the city of Newark-DE, United States.

\begin{tabular}{|c|c|c|c|c|c|}
\hline $\mathbf{N}^{\mathbf{o}}$ & Name & $\begin{array}{c}\text { Area } \\
\left(\mathrm{m}^{2}\right)\end{array}$ & $\mathbf{N}^{\mathbf{o}}$ & Name & $\begin{array}{l}\text { Area } \\
\left(\mathbf{m}^{2}\right)\end{array}$ \\
\hline 1 & Lumbrook Park & 38,938 & 15 & Norma B. Handloff Park & 107,322 \\
\hline 2 & Lewis Park & 42,379 & 16 & Elan Park & 42,481 \\
\hline 3 & Kershaw Park & 22,790 & 17 & Karpinski Park & 57,047 \\
\hline 4 & Kells Park & 30,835 & 18 & Leroy Hill Park & 42,253 \\
\hline 5 & Phillips Park & 124,694 & 19 & Douglas Dwight Alley Park & 5,712 \\
\hline 6 & Fairfield Crest Park & 24,768 & 20 & Folk Memorial Park & 137,367 \\
\hline 7 & Edna Dickey Park & 56,464 & 21 & Hidden Valley Park & 32,244 \\
\hline 8 & George Wilson Center and Park & 31,548 & 22 & William M. Redd Park & 488,075 \\
\hline 9 & George Read Park & 18,421 & 23 & Newark Reservoir & 758,121 \\
\hline 10 & Fairfield Park & 48,217 & 24 & Rahway Park & 5,742 \\
\hline 11 & Devon Park & 31,954 & 25 & White Chapel Park & 68,522 \\
\hline 12 & Rittenhouse Park & 422,600 & 26 & Stafford Park & 12,509 \\
\hline 13 & McKees Park & 27,520 & 27 & Ridgewood Glen Park & 21,680 \\
\hline \multirow[t]{2}{*}{14} & Curtis Mill Park & 129,128 & 28 & Olan Thomas Park & 19,950 \\
\hline & Total Area of UGSs & & & $2,849,281 \mathrm{~m}^{2}$ or $2.8 \mathrm{~km}^{2}$ & \\
\hline
\end{tabular}

Besides the high number of parks, these are still interconnected by a circuit of hiking, bicycle trails, etc. All the parks and trails are very well signposted and informative. An interactive map with all the necessary information for the users is still available online (Newark, 2016).
The city also has two state parks that border its urban boundaries and therefore have easy access for the population. The White Clay Creek State Park has an area of $20.5 \mathrm{~km}^{2}$, and the Iron Hill Park has a total area of 2.3 $\mathrm{km}^{2}$ (Figure 4). 


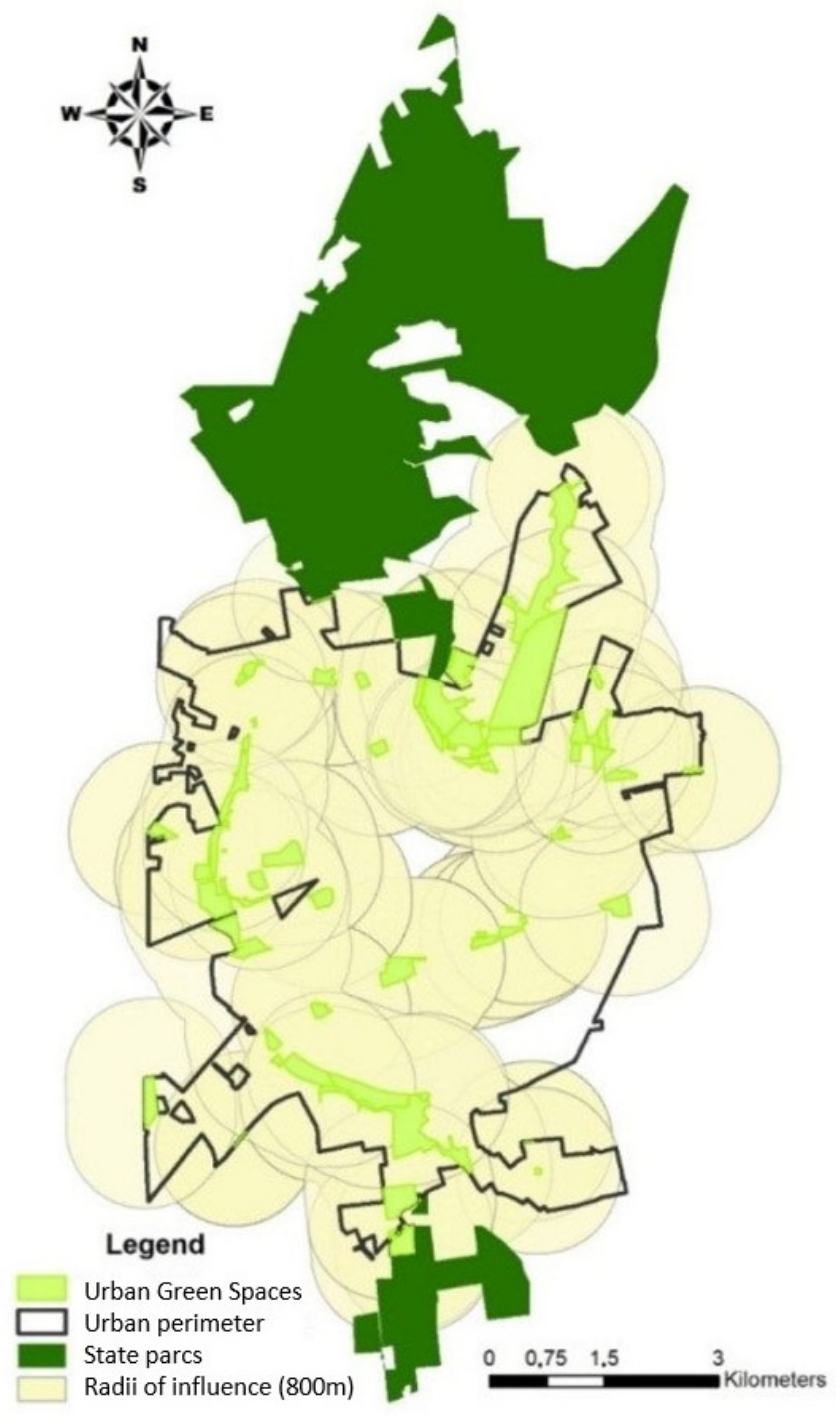

Figure 4. Urban parks of Newark (DE) and their radii of influence

The analysis of the radii of influence of the Newark urban parks and the results of GAI and GSR were not made considering the urban sectorization, and a homogeneous distribution of the UGSs in the city was found. Moreover, no demographic data were found in the Newark census with sector distinction for the city.

Similar studies were conducted in Baltimore (Maryland), near Newark, and the index found was 30.7 $\mathrm{m}^{2}$ inh $^{-1}$, with no homogeneous distribution of UGSs. The averages found in the USA range from 26 to 41 $\mathrm{m}^{2}$ inh $^{-1}$ (Boone, et al., 2009). Thus, it is observed that Newark-DE shows indices superior to those from other American cities.

The existence of these UGSs, as well as their quality and periodic maintenance in the city of Newark, are resulting from the work and supervision of a specific department of the City Hall, the Parks and Recreation Department, which has a landscaper responsible for the creation and adaptation of parks and UGSs. This department also has a board composed of specialists who assist in decision-making and management of these areas of the city (Newark, 2015).
Besides planning, implementing and supervising the proper functioning of the city's public parks, this council is still responsible for various community-based recreation activities, such as sports leagues, outdoor fairs, free classes for children and the elderly, among others. There is also a community incentive program for voluntary actions and adoption of these municipal parks (Newark, 2015).

The management of Newark's UGSs is based on Federal, State, and particularly on Municipal laws that define the responsibilities of the Parks and Recreation Department, as well as codes and rules for land use and occupation in urban space.

The Newark's municipal law considers not only the extent of allotment areas but also the population density residing on site. The minimum values of areas that should be allocated to public parks vary between $7 \%$ and $17 \%$. The percentage of UGSs increases proportionally to the number of dwellings per area. Also, $50 \%$ of these areas should not exceed a minimum of $3 \%$ natural slope and the rest of the terrain should not exceed $5 \%$ of natural slope. This law still has parameters and rules on equipment used, safety, recommended vegetation, among others. 
Comparative analysis of UGSs between Lavras-MG and Newark-DE

In the comparative analysis of the cities, it is possible to observe that the data obtained in Newark present indicators on the UGSs superior about the city of Lavras. Furthermore, the parks of Newark-DE have homogeneity in the urban framework much superior to the existing squares in the city of Lavras, which does not count as any park in the urban framework. Thus, in contrast to Lavras, the whole population in Newark has easy access to the UGSs near their place of residence.

Considering the public spaces in Lavras, only 30 have acceptable characteristics to be considered as UGSs, and the city has a GSR of $0.11 \%$ if considered the area of 54.6 $\mathrm{km}^{2}$ (IBGE, 2016) and $0.29 \%$ if considered $20.3 \mathrm{~km}^{2}$ as an urban territorial extension. On the other hand, the city of Newark has a total area of $41 \mathrm{~km}^{2}$, and there are 28 public urban parks with a total extension of $2.8 \mathrm{~km}^{2}$, representing $7 \%$ (GSR). These data demonstrate the similarity of the urban territorial extension of both cities and highlight the discrepancy of UGSs: the GSR of Newark is 20 times superior in comparison to the GSR of Lavras. To reach similar GSR of Newark, the city of Lavras would need to increase the UGSs to $3.76 \mathrm{~km}^{2}$ if analyzed the $54.6 \mathrm{~km}^{2}$ urban area or $1.362 \mathrm{~km}^{2}$ considering the urban extension of $20.3 \mathrm{~km}^{2}$.

Besides GSR, when analyzing the dimensions of each square of Lavras and its qualitative characteristics, the parks of Newark are superior in quality and extension. The average size of the areas considered as UGSs in Lavras is $1,812.8 \mathrm{~m}^{2}$, and this calculation not considered the outlier values of the largest UGSs (Praça Augusto Silva, 8,299 $\mathrm{m}^{2}$ ) and the smallest (Praça Artur Santos Peroni, 306 $\mathrm{m}^{2}$ ). In Newark, the average size of the parks, excluding the outliers (Newark Reservoir Park, 758,121 $\mathrm{m}^{2}$ and the Douglas Dwight Alley Park with 5,712 $\mathrm{m}^{2}$ ) was 80,210 $\mathrm{m}^{2}$. Thus it can be stated that the average size of Newark's UGSs is approximately 44 times greater than those found in Lavras.

Furthermore, all Newark parks presented adequate qualitative characteristics that allowed being evaluated as UGS. The vegetation of all UGSs of this city is planned, with adequate maintenance and all the parks showed one or more leisure options like playgrounds, skateboard and skate parks, soccer and baseball fields, multi-sport game courts, kiosk areas of picnic and barbecue, jogging and hiking trails, feeding. In contrast, in Lavras, besides the smaller, scarce and poorly distributed UGSs, many areas could not be considered as green spaces, since they did not show favorable characteristics to be considered as UGSs. When comparing GAI per inhabitant, the city of Newark has a value equal to $84.3 \mathrm{~m}^{2} \mathrm{inh}^{-1}$, without counting the floating population, which reduces to $50.2 \mathrm{~m}^{2} / \mathrm{inh}$ when it is included. However, the GAI of Lavras corresponds to $0.62 \mathrm{~m}^{2} /$ inh without counting the floating population and $0.54 \mathrm{~m}^{2} / \mathrm{inh}$ with the floating population. Even if Lavras had a population density similar to that of Newark ( 824.8 hab./ $\mathrm{km}^{2}$ ), i.e., 45,034 residents, since the GAI is calculated about the number of inhabitants, its GAI would be $1.31 \mathrm{~m}^{2}$ inh $^{-1}$ Thus, this confirms that city of Lavras is deficient in UGSs.

\section{Conclusions}

Lavras has a GAI $=0.62 \mathrm{~m}^{2} \mathrm{inh}^{-1}$ (without floating population) alternatively, $0.54 \mathrm{~m}^{2} \mathrm{inh}^{-1}$ (with floating population), as well as the GSR corresponding to $0.29 \%$. The GAI of Newark corresponds to $84.3 \mathrm{~m}^{2} \mathrm{inh}^{-1}$ (without the floating population) of $50.2 \mathrm{~m}^{2} \mathrm{inh}^{-1}$ (with the floating population). The GSR of Lavras corresponds to $0.11 \%$ and of Newark to $7.0 \%$.

There is a bad distribution of UGSs in the urban framework, and most of the regions and neighborhoods of Lavras do not have squares. In contrast, the distribution of public parks is homogeneous and covers all regions of Newark, thus providing easy access for the population to the UGSs.

\section{Author Contribution}

CSGG: project idea, research development, results analyses, graphs and figures preparation, manuscript writing and review. PDOP: project idea, manuscript writing and review. JB: project idea, manuscript writing and review. RBS: results analyses, graphs and figures preparation.

\section{Acknowledgments}

This work was supported with scholarships by Capes, CNPq, and FAPEMIG and the authors are thankful for all of them.

\section{References}

ARAÚJO, C.M.A.; FERREIRA, C.C.M. Áreas verdes públicas em Juiz de Fora, MG: Uma análise do estado da arte atual. Geo UERJ, v.2, n.25, p.250-275, 2014.

BARGOS, D.C.; MATIAS, L.F. Mapeamento E análise de áreas verdes urbanas em Paulínia (SP): Estudo com a aplicação de geotecnologias. Sociedade \& Natureza, v.24, n.1, p.143-156, 2012.

BARROS, M.V.F.; VIRGILIO, H. Praças: espaços verdes na cidade de Londrina. Geografia, v.12, n.1, 2003.

BOLDRIN, K.V.F.; GARCIA, C.S.G.; PAIVA, P.D.O.; CARVALHO, L.M. Quantitative inventory and analysis of the green areas in Lavras-MG and index evolution. Ornamental Horticulture, v.22, n.2, p.138-142, 2016. DOI: https://doi.org/10.14295/oh.v22i2.769

BOONE, C.G.; BUCLKEY, G.L.; GROVE, J.M.; SISTER, C. Parks and People: An Environmental Justice Inquiry in Baltimore, Maryland. Annals of the Association of American Geographers, v.99, v.4, p.767-787, 2009. 
BRESSANE, A.; MOCHIZUKI, P.S.; ROVEDA, J.A.F.; ROVEDA, S.R.M.M.; MEDEIROS, G.A.; RIBEIRO, A.I.; MARTINS, A.C.G. Sistema de apoio à gestão de áreas verdes urbanas. RevSbau, v.10, n.1, p.30 $\square 42,2015$.

CARVALHO, L.M.; PAIVA, P.D.O.; ACERBI JR., F.W.; COELHO, S.J.; SIMÕES, F.C. Caracterização e usos do Parque Florestal Quedas do Rio Bonito localizado na cidade de Lavras/MG-Pesquisa de opinião. Ciência e Agrotecnologia, v.27, n.6, p.1301-1307, 2003.

CARRUS, G.; SCOPELLITI, M.; LAFORTEZZAC, R.; COLANGELOC, G.; FERRINI, F.; SALBITANOE, F.; AGRIMIF, M.G.; PORTOGHESIF, L.; SEMENZATOG, P.; SANESIC, G. Go greener, feel better? The positive effects of biodiversity on the well-being of individuals visiting urban and peri-urban green areas. Landscape and Urban Planning, v.134, p.221-228, 2015. DOI: https://doi. org/10.1016/j.landurbplan.2014.10.022

CHIESURA, A. The role of urban parks for the sustainable city. Landscape and Urban Planning, v.68, p.129-138, 2004. DOI: https://doi.org/10.1016/j. landurbplan.2003.08.003.

COMUNE, M.D; SURINANI-AFFONSO, A.L. Análise de três áreas verdes urbanas em Guarapuava, Paraná. Ambiência, v.10, n.3, p.723-739, 2014.

DANTAS, A.A.A., CARVALHO, L.G.; FERREIRA, E. Classificação e tendências climáticas em Lavras, MG. Ciência e Agrotecnologia, v.31, p.1862-1866, 2007.

ESCOBEDO, F.J.; ADAMS, D.C.; TIMILSINA, N. Urban forest structure effects on property value. Ecosystem Services, v.12, p.209-17, 2015.

FERNANDES，C.J.; FERRAZ，M.V.; GIMENES，R.; PEREIRA, S.T.S.; PIVETTA, K.F.L. Trees description in the mais square of São José do Rio Petro, São Paulo State, Brazil. Ornamental Horticulture, v.24, n.4, p.334-340, 2018. DOI: https://doi.org/10.14295/oh.v24i4.1151

IBGE - Instituto Brasileiro de Geografia de Estatística Available at: $<$ http:// www.ibge.gov.br $>$. Accessed on: June $1^{\text {st }}, 2016$.

KABISCH, N.; HAASE, D. Green justice or just green? Provision of urban green spaces in Berlin, Germany. Landscape and Urban Planning, v.122, p.129-139, 2014. DOI: $10.1007 / 978-3-319-56091-5 \quad 12$

LAFORTEZZA, R.; CARRUS, G.; SANESI, G.; DAVIES, C. Benefits and well-being perceived by people visiting green spaces in periods of heat stress. Urban Forestry \& Urban Greening, v.2, p.97-108, 2009. https://doi. org/10.1016/j.ufug.2009.02.003
MUNICIPAL CODE. City of Newark, Delaware. Code of Ordinances Supplement 90 Update 2. Online content updated on August 29, 2016. Available at: <https://www. municode.com>. Accessed on: Sept 2, 2016.

NEWARK. Newark Delaware. Available at: $<\mathrm{http} / / / \mathrm{www}$. cityofnewarkde.us>. Accessed on: Oct 3, 2015.

NUCCI, J.C. Qualidade ambiental e adensamento urbano: um estudo de ecologia e planejamento da paisagem aplicado ao Distrito de Santa Cecília (MSP). São Paulo: USP, FFLCH, 2001. 236p.

PAIVA, P.D.O.; SOUSA, R.B.; CARCAUD, N. Flowers and gardens on the contexto and tourism potential. Ornamental Horticulture, v.26, n.1, p.121-133. DOI: https://doi. org/10.1590/2447-536X.v26i1.2144

PERSON, A.; MÖLLER, J.; ENGSTRÖM, K.; SUNDSTRÖM, M.L.; HOOIJEN, C.F.J. Is moving to a greener or less green area followed by changes in physical activity? Health \& Place, v.57, p.165-170, 2019. DOI: 10.1016/j.healthplace.2019.04.006.

RIGOLON, A. A complex landscape of inequity in access to urban parks: A literature review. Landscape and Urban Planning, v.153, p.160-169, 2016. DOI: https://doi. org/10.1177/0265813516672212

SCHEBELLA, M.F.; WEBER, D.; SCHULTZ, L.; WEINSTEIN, P. The wellbeing benefits associated with perceived and measured biodiversity in Australian urban green spaces. Sustainability, v.11, n.3, p.802, 2019. Doi: https://doi.org/10.3390/su11030802

SPAROVEK, G.; VAN LIER, Q.J.; NETO, D.D. Computer assisted Koeppen climate classification: a case study for Brazil. International Journal of Climatology, v.27, p.257-266, 2007. DOI: https://doi.org/10.1002/joc.1384

SALGADO, M.C.R.; PAIVA, P.D.O.; REIS, M.V.; GUIMARÃES, P.H.S.; GARCIA, C.S.G.; NASCIMENTO, A.M.P. Perfil e comportamento de usuários de espaço verde em cidade de pequeno porte. Revista Nacional de Gerenciamento de Cidades, v.8, n.58, p. 114-128, 2020.

SBAU-SOCIEDADEBRASILEIRADEARBORIZAÇÃO URBANA. "Carta a Londrina e Ibiporã". Boletim Informativo, v.3, n.5, p.3, 1996.

SILVA, R.A.; PEREIRA, J.A.A.; ALVES, S.F.N.S.C. The landscapes from Ouro Preto, Minas Gerais State: decoding in space and time. Ornamental Horticulture, v.25, n.1, p.9-17, 2019. DOI: https://doi.org/10.14295/oh.v25i1.1240 
SOUZA, M.R., SCOPEL, I., MARTINS, A.P. Áreas verdes no sítio urbano de Jataí (GO). Caminhos de Geografia, v.15, n.51, p.181-198, 2014.

TOLEDO, F.S.; MAZZEI, K.; SANTOS, D.G. Um índice de áreas verdes (IAV) na cidade de Uberlândia/MG. Revista da Sociedade Brasileira de Arborização Urbana, v.4, n.3, p.86-97, 2009.

UFLA. Universidade Federal de Lavras. Available at: $<\mathrm{http}$ ://www.ufla.br/portal $>$. Accessed on: Sept 15, 2016.

UNILAVRAS. Centro Universitário de Lavras. Available at: < http://www.unilavras.edu.br/site/>. Accessed on: Sept 15, 2016.
UNDP United Nations Development Programme. Available at: <http://hdr.undp.org/en/2016-report/ download>. Accessed on: Aug 12, 2016.

UNIVERSITY OF DELAWARE. Available at: < http:// www.udel.edu/students/>. Accessed on: Sept 26, 2015.

U.S Climate Data. Available at: $<$ http://www.usclimatedata. com $>$. Accessed on: Feb 20, 2016.

U.S. Census Bureau. Available at: < https://www.census. gov>. Accessed on: Aug 25, 2016. 